\title{
AN OVERVIEW OF INFANT DEMOGRAPHICS IN JAMMU
}

\section{PROVINCE (1981-2011)}

\section{RANKUSH KUMAR DALOTRA \& DEACHEN CHOROL}

Department of Geography, University of Jammu, Jammu and Kashmir, India

Health, as defined by the World Health Organization (WHO), is a state of absolute physical, mental and social well-being and not merely the absence of disease or infirmity. The present study is undertaken with the objective of assessing growth rate, birth rate and health status of Infants in the Jammu province. The sample of the present study is taken from Jammu province ensuring every possible representation of the population. During 1981 -2011, almost every district of the province shows negative to positive trend in the infant growth rate and birth rate. The positive trend of birth rate in Rajouri (-8.9 to $23.96 \%$ ) in worth mentioning.
\end{abstract}

KEYWORDS: Jammu, Infants, Birth Rate, Growth Rate \& Colostrum

Received: May 02, 2019; Accepted: May 22, 2019; Published: Jun 01, 2019; Paper Id.: IJEEFUSJUN201915

\section{INTRODUCTION}

Health is an elementary component of human development, and hence, defines society's well-being. It is a means to empower the depressed segments of society and thus, a significant element in the strategy for poverty alleviation. Access to anticipatory and protecting health care enriches entitlements of the poor by permitting steady employment, refining productivity and assisting demographic transition. The poor health substructure combined with low- income level and poverty has been a main cause of the poor health attainments of the nation. The vital statistics like Crude Birth Rate (CBR), Crude Death Rate (CDR), Infant Mortality Rate (IMR) and life expectancy at birth deliver the base for information on the health status and human progress of any area or country. These health parameters affect the prioritization of health issues, allocation of public capitals for health, formulation of effective schemes and implementation of health programmes. Health and socio-economic developments are so closely intertwined that it is impossible to attain one without the other. Health is the primary goal in its own right, as well as central input into commercial development and poverty alleviation. Refining the health of individuals, predominantly those belonging to socially and economically disadvantaged groups, has been an objective of the Indian government. A family is the chief social institution where one seeks love and affection; care and protection; and the satisfaction of his elementary physical, emotional and psychological needs. The changeover from joint family structure to a nuclear family, coupled with the rising cost of daily necessities and various other economic and social obligations are compelling causes to take gainful employment, (part-time or full-time), to supplement the family earnings. A huge number of families, both in rural and urban areas of the nation, are below the poverty line. Some segments of the society, viz. i) urban slum dwellers, ii) marginal farmers and agrarian landless labourers, iii) tribal's and iv) scheduled caste people are specifically underprivileged. In spite of significant progress in the economy, these sections of society are not in a position to offer due care and security needed for normal growth of their children even today. Consequently, they want additional support through outside intrusions to enable the 
family to fulfill its duties towards appropriate health care, nutrition, education and social well- being of their children.

\section{OBJECTIVES OF THE STUDY}

- To examine the Growth and Birth rate of Infants in the study area.

- To assess the health status of Infants in the study area.

\section{DATA BASE AND RESEARCH METHODOLOGY}

\section{Data Source}

The present research is based on the both primary as well as secondary sources of data. The secondary sources of the data were gathered from the state Health department.

The primary data has been collected with the help of well-structured questionnaires. For primary survey, 60 households from each villages of the province were randomly selected, which further was divided into each 30 household belonging to the rural and urban area of the province. The selection was made on the various parameters like socioeconomic and health status.

\section{Methods}

The data are then tabulated and analyzed by using various statistical techniques like simple average percentage method and growth of population which goes like;

$$
\mathrm{P} . \mathrm{R}=\frac{(V . \text { Present }-V . \text { Past })}{\frac{V . \text { Past }}{10}} \times 100
$$

Where,

$P . R=$ denotes the percent growth rate of population

V.P $P_{\text {resent }}=$ denotes current year population

V. $P_{\text {ast }}=$ denotes the base year population

The annual growth rate of the population since 1981-2011 of Jammu district has been calculated by using the formula given above.

\section{Study Area}

Jammu province in the northern most state of India's Jammu and Kashmir lies between $32^{\circ}$ degree $17^{\prime}$ to $34^{\circ}$ degree $12^{\prime}$ North latitude and $73^{\circ}$ degree $58^{\prime}$ to $76^{\circ}$ degree $47^{\prime}$ East longitude.It is spread over an area of $26293 \mathrm{~km}^{2}$. The region is bordered by the valley of Kashmir in the north, Kargil district in the north-east, Chamba district (Himachal Pradesh) in the south-east, Gurdaspur District (Punjab) in the southand Pakistan and Pakistan occupied territory of Kashmir in the west. Attitudinally; the region spreads on 300 meters above mean sea level in the outer plains to over 5000 meters in middle Himalayas. Administratively, Jammu province was made up of six districts viz. Jammu, Kathua, Udhampur, Doda, Rajouri and Poonch (Census 2001); which after 2001 increased to 10 thus adding Samba, Reasi, Kishtwar and Ramban to the list. 


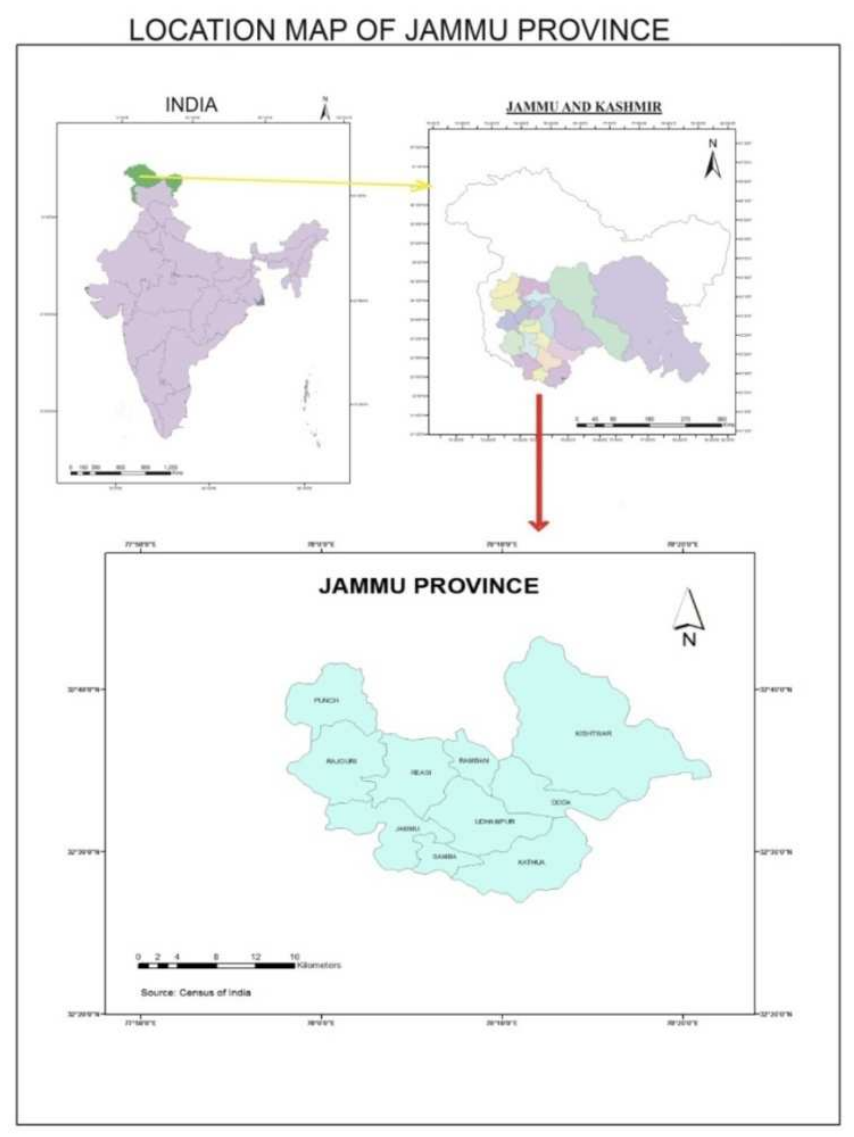

Figure 1: Location Map of Jammu Province

\section{RESULTS AND DISCUSSIONS}

Taking into consideration the importance of both published and ground information, the study is formulated on the basis of both secondary and primary source of information. There is a gap in the proper analysis of the situation as some of the districts been created only after 2001; which consequently weakens the study on temporal change in Infant birth rate or growth rate and so on. The first three table deals with the data from the Census of India where the remaining two three table are based in the sampled survey.

\section{Infant Population}

It encompasses that proportion of the total population of the country; which lies in the age group of 0-6 years. It is an important indicator since it overlooks a delicate segment of the population. India is the second most populous country in the world where 13.12 percent of her population lies in the tender age group of 0-6 years as per the provisional Census 2011 figures. 
Table 1: District Wise Infant Population in Jammu Province (1981, 2001 \& 2011)

\begin{tabular}{|c|c|c|c|c|c|c|c|c|c|}
\hline \multirow{3}{*}{ Districts } & \multicolumn{9}{|c|}{ Year } \\
\hline & \multicolumn{3}{|c|}{1981} & \multicolumn{3}{|c|}{2001} & \multicolumn{3}{|c|}{2011} \\
\hline & $\begin{array}{c}\text { Total } \\
\text { Population }\end{array}$ & Male & Female & $\begin{array}{c}\text { Total } \\
\text { Population }\end{array}$ & Male & Female & $\begin{array}{c}\text { Total } \\
\text { Population }\end{array}$ & Male & Female \\
\hline Jammu & 297940 & 185558 & 112382 & 198825 & 106480 & 92345 & 167363 & 93242 & 74121 \\
\hline Kathua & 115184 & 66948 & 48236 & 81302 & 43046 & 38256 & 83936 & 45833 & 38103 \\
\hline Udhampur & 138244 & 76074 & 62270 & 121446 & 69101 & 52345 & 84332 & 44703 & 39629 \\
\hline Rajouri & 136177 & 75589 & 60588 & 79394 & 48138 & 48138 & 108271 & 58051 & 50220 \\
\hline Poonch & 128198 & 69075 & 59123 & 67059 & 33808 & 33251 & 84674 & 44733 & 39941 \\
\hline Doda & 118661 & 66315 & 52346 & 119031 & 66662 & 52369 & 71240 & 36862 & 34378 \\
\hline Samba & - & - & - & - & - & - & 38669 & 21737 & 16932 \\
\hline Reasi & - & - & - & - & - & - & 55799 & 29079 & 26720 \\
\hline Kishtwar & - & - & - & - & - & - & 39396 & 20479 & 18917 \\
\hline Ramban & - & - & - & - & - & - & 55092 & 28625 & 24467 \\
\hline $\begin{array}{c}\text { Grand } \\
\text { Total }\end{array}$ & 934404 & 539559 & 394945 & 667057 & 367235 & 316704 & 691328 & 423344 & 363428 \\
\hline
\end{tabular}

Source: Census of India Report. 1981, 2001\& 2011

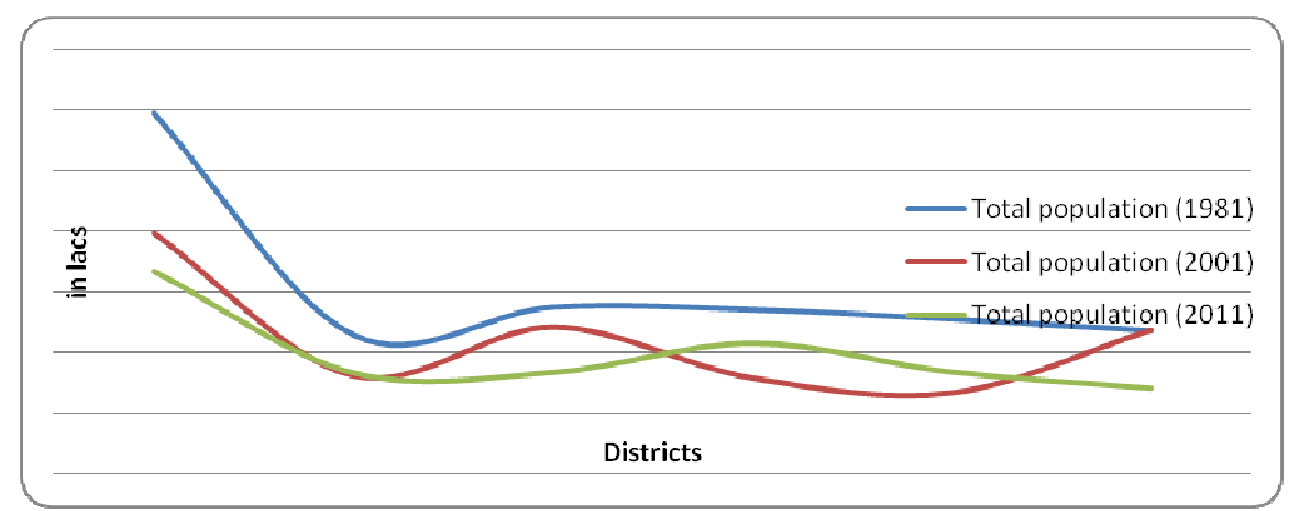

Figure 2: District wise Infant Population in Jammu Province (1981, 2001 \& 2011)

Table no.1 deals with the scenario of district wise Infant population (0-6 years) in the Jammu province. A thorough investigation of the data reveals that Jammu tops the list of districts with maximum Infant population all through 1981 to 2011. Though the district had retained the title of district with maximum Infant population, but the numbers have declined from 297940 in 1981 to198825 in 2001 and further to 167363 in 2011 . Interestingly, the title of district with minimum Infant population keeps on changing from Udhampur (115184) in 1981 to Poonch (67059) in 2001 and to Samba (38669) in 2011.The separate analysis on sex wise Infant population, Jammu stands alone in the group of districts and had continuously tops the rank of male and female population. The total male Infant population in Jammu during 1981 was 185558; which further decreases to 106480 in 2001 and 93242 in 2011. On the contrary, Doda (66315) had least number of male Infant populations; similar is for Kathua (43046) in 2001 and Kishtwar (39396) in 2011. Jammu district again tops list with maximum female Infant population. The recorded figures were 112382 in 1981 , which also decreases to 92345 in 2001 and 74121 in 2011. The districts with least female Infant population during 1981, 2001 and 2011 were Kathua (48236), Poonch (33251) and samba (16932). 
Table 2: District Wise Growth Rate Amongst Infant Population in Jammu Province (1981, 2001 \& 2011$)$

\begin{tabular}{|c|c|c|c|c|c|}
\hline \multirow{3}{*}{ District } & \multicolumn{5}{|c|}{ Year } \\
\hline & \multicolumn{3}{|c|}{ Infant Population } & \multirow{2}{*}{$\begin{array}{c}\text { Growth Rate in \% } \\
\text { Age(1981-2001) }\end{array}$} & \multirow{2}{*}{$\begin{array}{c}\text { Growth Rate in \% } \\
\text { Age(2001-2011) }\end{array}$} \\
\hline & 1981 & 2001 & 2011 & & \\
\hline Jammu & 297940 & 198825 & 167363 & -3.3 & -1.57 \\
\hline Kathua & 115184 & 81302 & 83936 & -2.94 & 0.32 \\
\hline Udhampur & 138244 & 121446 & 84332 & -1.21 & -3.05 \\
\hline Rajouri & 136177 & 79394 & 108271 & -4.16 & 3.63 \\
\hline Poonch & 128198 & 67059 & 84674 & -4.72 & 2.62 \\
\hline Doda & 118661 & 119031 & 71240 & 0.03 & -4.01 \\
\hline Samba & - & - & 38669 & - & - \\
\hline Reasi & - & - & 55799 & - & - \\
\hline Ramban & - & & 39396 & - & - \\
\hline Kishtwar & - & & 55092 & - & - \\
\hline
\end{tabular}

Source: Census of India Report; 1981, $2001 \& 2011$.

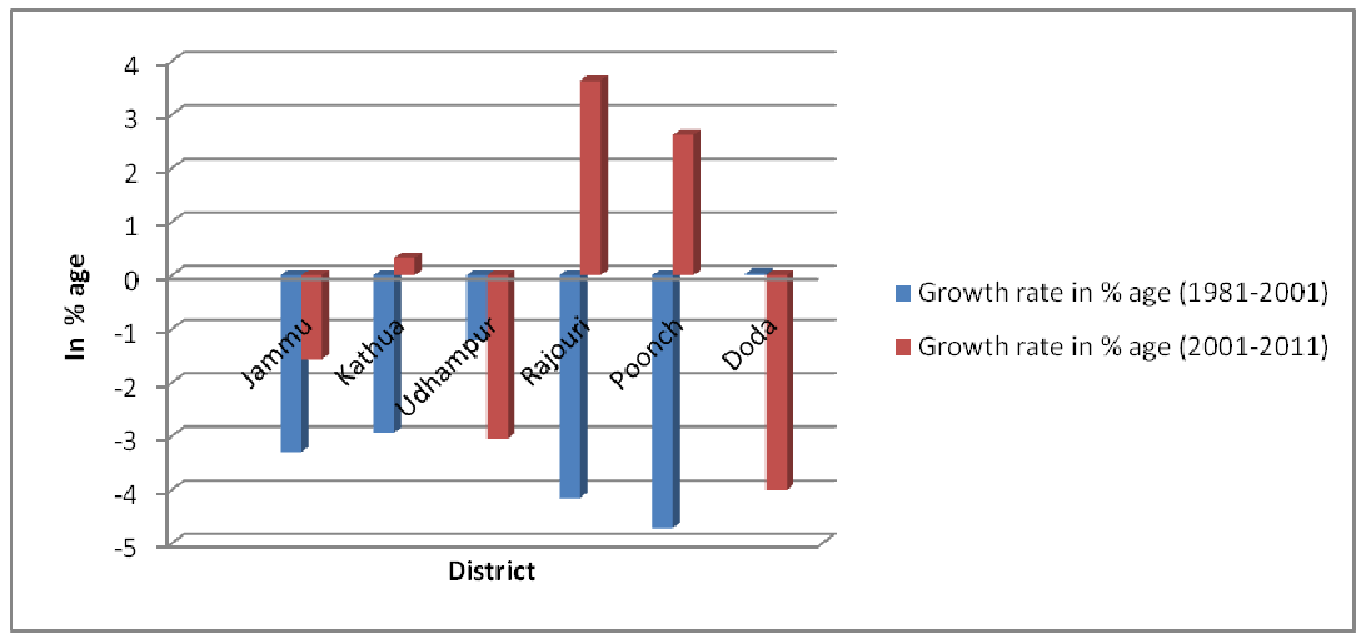

Figure 3: District Wise Growth Rate Amongst Infant Population in Jammu Province (1981, 2001 \& 2011)

Table no. 2 deals with district wise growth rate amongst Infant population in Jammu province. The finding shows that Doda $(0.03 \%)$ is the only district in the province to have positive Infant growth rate during 1981-2001. Districts like Poonch (-4.72\%), followed by Rajouri (-4.16\%) and Kathua (-2.94\%) saw a major decline in Infant growth rate during 1981-2001.The list of district with positive growth rate increases to kathua, Rajouri and Poonch during 2001-2011,like wise the list of district with negative growth rate decreases to Jammu, Udhampur and Doda. The major decline in the Infant growth rate was witnessed in Doda (-4.01\%),Udhampur (-3.05\%) and Jammu (-1.57\%), likewise the increase was recorded in Rajouri $(3.63 \%)$, Poonch $(2.62 \%)$ and Kathua $(0.32 \%)$. The district showing positive trend in Infant growth rate during 1981-2011 are Rajouri (-4.16 to 3.63\%), Poonch (-4.73 to $2.62 \%)$ and Kathua (-2.94\% to $0.32 \%)$. The only district with a negative growth rate is Doda $(0.03$ to $-4.01 \%)$.

\section{Order of Childbirth in the Families}

Birth order refers to the order in which a child is born in a family such as first-born and second-born. Birth order is often believed to have some to profound effect on attitudinal and psychological development of a child. Nevertheless, the notion that birth-order significantly influences personality continues to have a strong presence in popular culture. In addition, the Government of India (GOI) and the World Health Organization (WHO) have launched national programs of 
medical care and precautionary medicine which, on the basis of recent surveys, appears effective in lowering the incidence of smallpox, cholera, plague, malaria, tuberculosis, and venereal diseases.

Table 3: District Wise Birth Rate Amongst Infant Population (1981, 2001 \& 2011)

\begin{tabular}{|c|c|c|c|c|c|}
\hline \multirow{3}{*}{ District } & \multicolumn{5}{|c|}{ Year } \\
\hline & \multicolumn{3}{|c|}{ Total Birth Taken Place } & \multirow{2}{*}{$\begin{array}{l}\text { Birth Rate in \% } \\
\text { Age(1981-2001) }\end{array}$} & \multirow{2}{*}{$\begin{array}{l}\text { Birth Rate in \% } \\
\text { Age(2001-2011) }\end{array}$} \\
\hline & 1981 & 2001 & 2011 & & \\
\hline Jammu & 20691 & 31395 & 20200 & 5.17 & -3.56 \\
\hline Kathua & 13750 & 14018 & 21902 & 0.19 & 5.62 \\
\hline Udhampur & 10899 & 8545 & 16022 & -2.12 & 8.7 \\
\hline Rajouri & 1610 & 1522 & 2227 & -0.55 & 4.7 \\
\hline Poonch & 4978 & 520 & 1766 & -8.9 & 23.96 \\
\hline Doda & 9122 & 1145 & 3233 & -8.74 & 18.23 \\
\hline Samba & - & - & 6834 & - & - \\
\hline Reasi & - & - & 9918 & - & - \\
\hline Ramban & - & - & 1245 & - & - \\
\hline Kishtwar & - & - & 1627 & - & - \\
\hline
\end{tabular}

Source: Department of economics and statistics (J\&K), 2014-2015

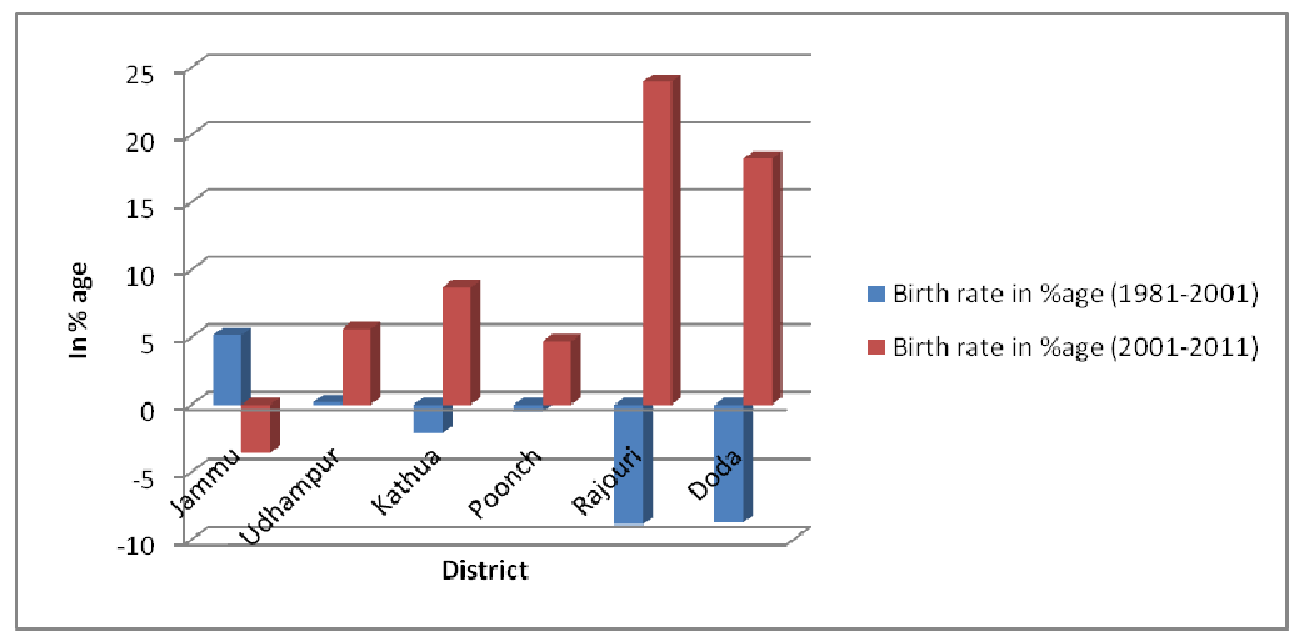

Figure 4: District Wise Birth Rate Amongst Infant Population (1981, 2001 \& 2011)

Table no. 3 deals with the district wise birth rate in Infant population in Jammu province. The province in general have witnessed both positive (Jammu \&Udhampur) and negative (Kathua, Poonch, Rajouri and Doda) Infant birth rate during 1981-2001. While there were major decline in Infant birth rate in Rajouri (-8.9\%) and Doda (-8.74\%); the districts of Jammu (5.17\%) and Udhampur (0.19\%) has increase in Infant birth rate. During 2001-2011, the number of the districts with positive Infant birth rate increases to Udhampur, Kathua, Poonch, Rajouri and Doda. Jammu (-3.56\%) remained the only district with negative birth rate. The highest share of Infant birth rate was recorded in Rajouri (23.96\%) and Doda (18.23\%). Kathua, Rajouri, Poonch and Doda were amongst the 6 district; which has recorded negative to positive trend in Infant birth rate. While Jammu (5.17 to $-3.56 \%$ ) recorded negative trend during $1981-2011$; Udhampur (0.19 to 5.62\%) which had negligible but positive birth rate in the province has still managed to remain the same. 
Table 4a: District Wise Child Mortality, 2014-15 (Rural)

\begin{tabular}{|l|c|c|c|c|c|c|c|c|}
\hline \multirow{2}{*}{ District } & \multicolumn{9}{|c|}{ Rural (\%) } \\
\cline { 2 - 10 } & Child mortality & \multicolumn{2}{c|}{ If yes, then Age at Death of the Children } & \multicolumn{2}{c|}{ Sex of Child } \\
\hline & Yes & No & Within 7 Days & in 1 Month & in 1 Year & And 1-4 Year & Male & Female \\
\hline Jammu & 20.00 & 80.00 & 50.00 & - & 50.00 & - & 50.00 & 50.00 \\
\hline Samba & 26.66 & 73.34 & 20.66 & 39.34 & - & 40.00 & 66.66 & 33.34 \\
\hline Kathua & 30.00 & 70.00 & 40.00 & - & 60.00 & - & 39.34 & 60.66 \\
\hline Udhampur & 20.00 & 80.00 & - & 50.00 & - & 50.00 & 49.34 & 51.66 \\
\hline Reasi & 26.66 & 73.34 & 53.34 & - & - & 46.66 & 46.66 & 53.34 \\
\hline Rajouri & 20.00 & 80.00 & 100.00 & - & - & - & 50.00 & 50.00 \\
\hline Poonch & 30.00 & 70.00 & 66.66 & 23.34 & - & - & 66.66 & 34.34 \\
\hline Doda & 20.00 & 80.00 & 33.34 & 66.66 & - & - & 49.34 & 51.66 \\
\hline Kishtwar & 16.66 & 73.34 & 23.34 & 76.66 & - & - & 100.00 & - \\
\hline Ramban & 23.34 & 76.66 & 43.34 & 56.66 & - & - & 33.34 & 56.66 \\
\hline Average Total & $\mathbf{2 3 . 3 2}$ & $\mathbf{7 5 . 6 6}$ & $\mathbf{4 3 . 0 6}$ & $\mathbf{3 1 . 2 6}$ & $\mathbf{1 1 . 0 0}$ & $\mathbf{1 3 . 6 6}$ & $\mathbf{5 5 . 1 3}$ & $\mathbf{4 4 . 1 6}$ \\
\hline
\end{tabular}

Source: Based on Field survey, 2014-2015

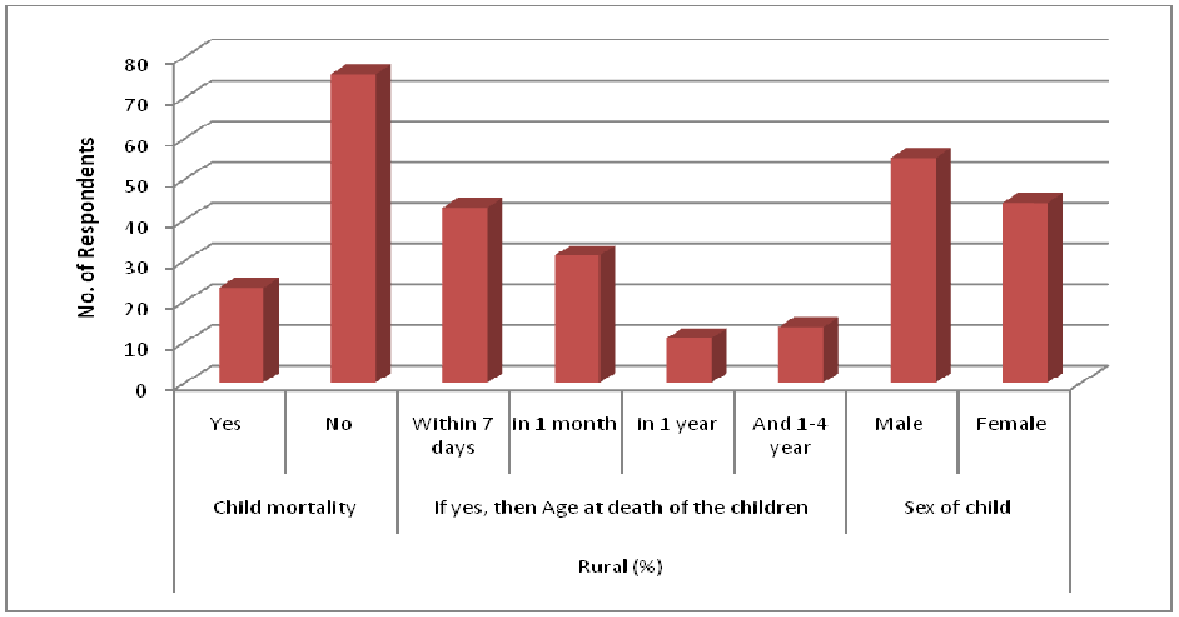

Figure 5a: District Wise Child Mortality, 2014-15 (Rural)

Table no. 4a deals with the district wise Infant mortality in rural areas of Jammu province. An examination of the data suggests that out of all the sampled population; Kathua and Poonch (30\%) have the highest Infant mortality rate. On the other hand Jammu, Udhampur, Rajouri and Doda (80\%) were amongst the district were Infant mortality was recorded at its lowest. On the question of maximum death in respective time periods, Rajouri (100\%) tops the list with Infant mortality within 7 days, likewise Kishtwar (76.66\%) within a months' time, Kathua (60\%) within a year and Udhampur (50\%) within 1-4 years if childs' birth. On the basis of sex ( male\& female) maximum male Infant mortality is recorded in Kishtwar (100\%) followed by Poonch (86.66\%) and viseversa in Jammu (100\%) and Reasi (51.66\%). 
Table 4b: District Wise Child Mortality, 2014-15 (Urban)

\begin{tabular}{|l|c|c|c|c|c|c|c|c|}
\hline \multirow{2}{*}{ District } & \multicolumn{7}{|c|}{ Urban (\%) } \\
\cline { 2 - 10 } & Child Mortality & \multicolumn{2}{|c|}{ If yes, then Age at Death of the Children } & \multicolumn{2}{c|}{ Sex of Child } \\
\hline & Yes & No & Within 7 Days & in 1 Month & in 1 Year & And 1-4 Year & Male & Female \\
\hline Jammu & 10.00 & 90.00 & 100.00 & - & - & - & - & 100.00 \\
\hline Samba & 23.34 & 76.66 & 66.66 & 34.33 & - & - & 73.34 & 26.66 \\
\hline Kathua & 16.66 & 83.34 & 73.34 & 26.66 & - & - & 13.34 & 10.00 \\
\hline Udhampur & 13.34 & 86.66 & 63.34 & & 26.66 & - & 83.34 & 16.66 \\
\hline Reasi & 20.00 & 80.00 & 83.34 & 26.66 & - & - & 49.34 & 51.66 \\
\hline Rajouri & 16.66 & 83.34 & 66.66 & 33.34 & - & - & 66.66 & 33.34 \\
\hline Poonch & 26.66 & 73.34 & 50.00 & 50 & - & 6.66 & 86.66 & 13.34 \\
\hline Doda & 20.00 & 80.00 & 73.34 & 26.66 & - & - & 73.34 & 26.66 \\
\hline Kishtwar & 10.00 & 90.00 & 66.66 & 33.34 & - & - & 100.00 & - \\
\hline Ramban & 13.34 & 86.66 & 56.66 & 43.33 & 3.34 & - & 73.34 & 26.66 \\
\hline $\begin{array}{c}\text { Average } \\
\text { Total }\end{array}$ & $\mathbf{1 7 . 0 0}$ & $\mathbf{8 3 . 0 0}$ & $\mathbf{7 0 . 0 0}$ & $\mathbf{2 7 . 4 3}$ & $\mathbf{3 . 0 0}$ & $\mathbf{0 . 6 6}$ & $\mathbf{6 1 . 9 3}$ & $\mathbf{3 0 . 4 9}$ \\
\hline
\end{tabular}

Source: Based on Field survey, 2014-2015

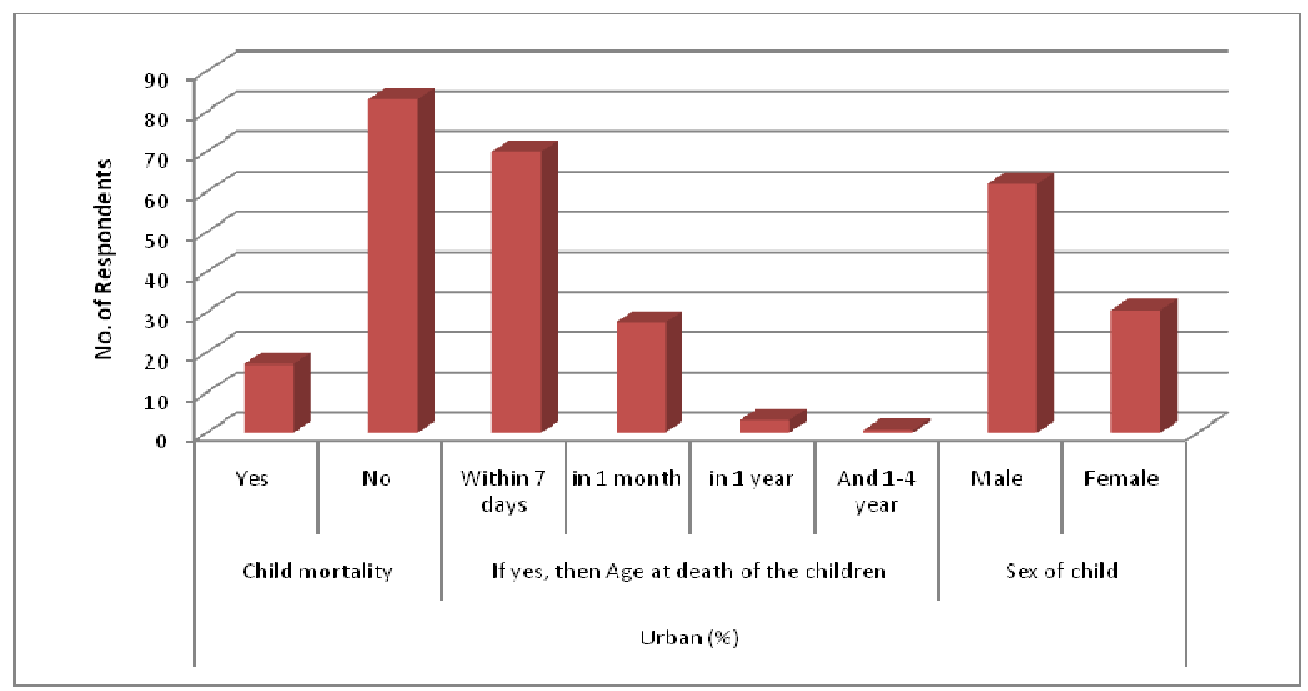

Figure 5b: District Wise Child Mortality, 2014-15 (Urban)

Table no. $4 \mathrm{~b}$ deals with the district wise Infant mortality in urban areas of Jammu province. An examination of the data suggests that out of all the sampled population; Poonch $(26.66 \%)$ and Samba (23.34\%) have high rate of Infant mortality. Jammu and Kishtwar (90\%) has recorded least Infant mortality. Poonch (50\%) has maximum Infant mortality both in the category of within 7 days and within a month. Udhampur (26.66\%) had maximum mortality of children who are still to complete a year. On the basis of sex (male \& female) maximum male mortality is recorded in Kishtwar (100\%) and Poonch $(86.66 \%)$ and vice versa in Jammu (100\%) and Reasi (51.66\%). 
Table 5: District Wise Information on Weight of Infant and Colostrum Given to the Newly Born, 2014-15 Infant

\begin{tabular}{|c|c|c|c|c|c|c|c|c|c|c|}
\hline \multirow{3}{*}{ District } & \multicolumn{5}{|c|}{ Rural } & \multicolumn{5}{|c|}{ Urban } \\
\hline & \multicolumn{3}{|c|}{$\begin{array}{l}\text { Weight of Infant at the } \\
\text { Time of Birth (\%age) }\end{array}$} & \multicolumn{2}{|c|}{$\begin{array}{l}\text { Colostrum } \\
\text { Given to the } \\
\text { Newly Born }\end{array}$} & \multicolumn{3}{|c|}{$\begin{array}{c}\text { Weight of Child at the Time of } \\
\text { Birth (\%age) }\end{array}$} & \multicolumn{2}{|c|}{$\begin{array}{l}\text { Colostrum } \\
\text { Given to the } \\
\text { Newly Born }\end{array}$} \\
\hline & $\begin{array}{c}3-3.50 \\
\text { kg }\end{array}$ & $\begin{array}{c}\text { Less } \\
\text { than } 3 \\
\text { kg }\end{array}$ & $\begin{array}{l}\text { Don't } \\
\text { know }\end{array}$ & Yes & No & $3-3.50 \mathrm{~kg}$ & $\begin{array}{c}\text { Less } \\
\text { than } 3 \mathrm{~kg}\end{array}$ & $\begin{array}{l}\text { Don't } \\
\text { know }\end{array}$ & Yes & No \\
\hline Jammu & 40.00 & 20.00 & 20.00 & 80.00 & - & 40.00 & 16.66 & 3.34 & 63.33 & - \\
\hline Samba & 30.00 & 30.00 & 16.66 & 76.66 & - & 40.00 & 26.66 & - & 66.66 & - \\
\hline Kathua & 50.00 & 20.00 & 20.00 & 90.00 & - & 50.00 & 20.00 & - & 70.00 & - \\
\hline Udhampur & 40.00 & 13.33 & 20.00 & 73.33 & - & 60.00 & 26.66 & - & 86.66 & - \\
\hline Reasi & 40.00 & 20.00 & 13.33 & 73.33 & - & 70.00 & 16.66 & - & 83.33 & - \\
\hline Rajouri & 50.00 & 23.34 & 6.66 & 80.00 & - & 60.00 & 10.00 & 13.34 & 73.33 & - \\
\hline Poonch & 40.00 & 23.33 & 20.00 & 83.34 & - & 50.00 & 26.66 & - & 76.66 & - \\
\hline Doda & 20.00 & 3.33 & 23.33 & 66.66 & - & 60.00 & 00.00 & 10.00 & 70.00 & - \\
\hline Kishtwar & 33.33 & 20.00 & 20.00 & 73.33 & - & 70.00 & 13.34 & - & 83.33 & - \\
\hline Ramban & 30.00 & 16.66 & 20.00 & 66.66 & - & 60.00 & 10.00 & - & 70.00 & - \\
\hline $\begin{array}{c}\text { Average } \\
\text { Total }\end{array}$ & 37.66 & 19.66 & 15.99 & 76.99 & - & 56.00 & 16.66 & 1.66 & 74.33 & - \\
\hline
\end{tabular}

Source: Based on Field Survey, 2014-2015

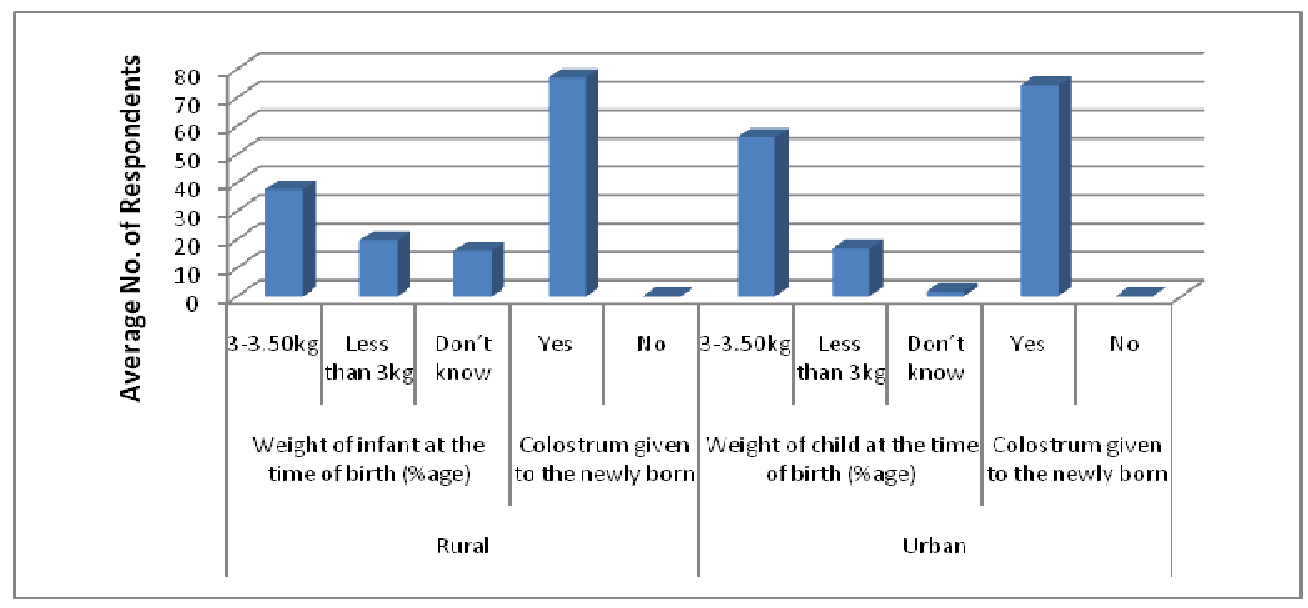

Figure 6: District Wise Information on Weight of Infant and Colostrum Given to the Newly Born, 2014-15

Table no. 5 deals with the district wise information on weight of the Infant and Colostrum given to the newly born in rural as well as urban areas of Jammu province. On the question of weight of Infant at birth in rural areas of the province; Kathua and Rajouri (50\%) tops the category of 3-3.5kg weight, likewise Samba (30\%) and Rajouri (23.34\%) tops in the category of weight less than $3 \mathrm{~kg}$. Amongst all the rural area, Doda (23.33\%) tops the list where respondent did not have the record. Kathua (90\%), followed by Poonch $(83.34 \%)$ has maximum population who agreed on Colostrum being given to their new born. In context of urban areas of Jammu province; Reasi and Kishtwar (70\%) tops in the category of 3-3.5kg weight, likewise Udhampur and Poonch (26.66\%) tops in the category of weight less than $3 \mathrm{~kg}$. And amongst all the urban areas, Rajouri (13.34\%) have the maximum number of population where they did not have the record. Udhampur $(86.66 \%)$, followed by Kishtwar $(83.33 \%)$ has maximum population who have given Colostrum to their child. 


\section{CONCLUSIONS}

The interest of the population geographers in the study of mortality, however, lies primarily in it being a basic component of population growth with a view to measuring the Infant mortality. Health is one of the important parameters of human development index. The status of health and resultant fertility and mortality are indicators of development of any region. The Objectives of the study was to examine the growth rate amongst the Infants and also to assess their present health scenario in Jammu province. The findings shows are such that though the district of Jammu under Jammu province managed to remain intact at the top list of district with maximum Infant population all through 1981 to 2011; but there is always a decline in the number with every proceeding year. Same is the case with total male and female infant population. In the context of Infant growth rate, three districts of Jammu province namely; Poonch (-4.72 to 2.62\%), Rajouri (-4.16 to $3.63 \%$ ) and Kathua (-2.94 to $0.32 \%$ ) has displayed negative to positive trend during 1981 to 2011. Likewise; the districts showing positive trend in Infant birth rate are Rajouri (-8.9 to 23.96\%), Doda (-8.74 to 18.23\%), Kathua (02.12 to 8.7\%) and Poonch (-0.55 to 4.7\%). In case of Infant mortality, urban Jammu and KIshtwar recorded maximum mortality rate compared to the highest (Kathua and Poonch) in rural area of the province. The record on the weight at the time of birth suggests that urban area of Reasi and Kishtwar district have maximum (70\%) child born under the weight range of 3- 3.5 $\mathrm{kg}$ and likewise it is for rural area of Samba district (30\%) where the maximum infant falls into the range of less than $3 \mathrm{~kg}$ weight. When questioned about the first milk given to the baby right after birth, rural area of the Kathua district (90\%) tops the list of the district both its rural and urban areas to actually have agreed on the instance of providing colostrums to the baby.

\section{REFERENCES}

1. Abuzar, M. (1988). Socio-Economic aspects of Population Structure. Jaipur: Rawat Publication.

2. Ababneh, A. A. A., M Al-Ja'freh, S., \& Abushaikha, L. (2017). Traumatic Childbirth: Incidence, Risk Factors, and Its Impact on Mothers and Their Infants a Scoping Review. International Journal of Applied and Natural Sciences (IJANS), 6(6), 1-8.

3. Bhuiya, A., and Straetfield, k. (1992). AHazardLogit Model Analysis of Covatiaties of Child Mortality in Matlab, Bangladesh. Journal of Bio social Science 24,447-462.

4. Bose, A. (1991). Demographic diversity in India. New Delhi: D.K Publishers distribution,

5. Das, B. (2018). Dependency Ratio and North East India: In the Wave of Demographic Transformation.

6. Gupta, M.D., (1990). Death clustering, mothers' education and determinants of Child mortality in rural Punjab, India. Population studies, 44(3), 489-505.

7. Hari, M., (1991). Modernization, status of Women and Fertility. The Journal of Family Welfare. June, 37(2), 62-67.

8. Kammeyar (1988).An Introduction to the population. New Delhi: Published at Sandeep Lal for archive books,

9. Miller, J.E., Trussell, J.,Pebley, A.R., and Vaughan, B. (1992). Birth spacing and child mortality in Bangladesh and the Phillippines. Demography, 29(2), 305-318.

10. Prakasam, C.P., and Murthy, P.K. (1989). Social amenities and Infant mortality in rural India.Dynamics of Population and Family Welfare (ed) K. Srinivasan and K.B. Pathak, Bombay: Himalayan Publishing House, 109-119. 